\title{
Curriculum Teaching of English and American Literature under the Guidance of Constructivism Theory
}

\author{
Xiuye Zeng \\ College of Foreign Languages, Bohai University, Jinzhou, 121013, China \\ 1493181828@qq.com
}

Keywords: constructivism theory; English and American literature; course teaching; teaching present situation; theoretical basis; teaching strategies

\begin{abstract}
British and American literature teaching core task is to help students master the basic knowledge of English and American literature, and strengthen their understanding and appreciation of British and American literature, improve the students found the problem, the ability to analyze and solve problems, the critical thinking habit, improve humanities accomplishment. In view of the present not enough emphasis on curriculum, teaching process ignored humanistic quality training, students' interest is not high and the textbook problem such as adaptability is not strong, in this paper, the basic theory of constructivism, with reference to relevant literature, combined with British and American literature teaching and research experience for many years, puts forward the multiple perspectives analysis literature, carrying out cultural teaching, and make full use of multimedia assisted teaching strategies to improve the teaching quality.
\end{abstract}

\section{Introduction}

People's Republic of China ministry of education approved the implementation of the outline of college English teaching for English majors of important guiding significance for the national all kinds of English major, is teaching for English majors in colleges and universities organization and check the quality of teaching, writing teaching material basis, is to implement and carry out the approval issued by the ministry of education of the People's Republic of China on foreign language professional undergraduate course education reform facing the 21st century the several opinions of the important guarantee. Syllabus points out that English professional knowledge courses including literature, linguistics course curriculum and social culture. Among them the purpose of literature courses is to cultivate students the ability of reading, appreciation and understanding of English literature, master the basic knowledge and methods of literary criticism. Through reading and analysis of British and American literature, and to promote students' language basic skill and the improvement of humanistic quality, enhance students' understanding of western literature and culture. Teaching content can include an introduction to literature, a profile of the British literature, American literature and literary criticism.

British and American literature teaching core task is to help students master the basic knowledge of English and American literature, and strengthen their understanding and appreciation of British and American literature, improve the students found the problem, the ability to analyze and solve problems, the critical thinking habit, improve humanities accomplishment. At the same time, British and American literature course is English major students' knowledge level, practice ability and cultural accomplishment. Through the study of this course, not only broaden the students' English language knowledge and language skills, and to improve the students' ability of autonomous learning and language practice innovation ability. At the same time, through reading and analyzing literature, master the methods of appreciating literary works, and understand the work of thinking, literature value and writing skills; By appreciating the artistic features of literary works, to understand the writer's creation tendency and the thought method, understand the well-known home position in the literary history and achievements, and art style's impact on world literature. In a comprehensive understanding of British and American national literature in different historical periods, features and content on the basis of the representative works, learn the art of analyzing the 
characteristics, grasp the correct evaluation standard and methods of the literature, comprehensively improve the level of language, and enhance the work performance of the social life and the understanding of the emotion, improve the level of all kinds of reading and appreciation of literary works.

\section{Present Situation on English and American Literature Teaching}

English teaching in colleges and universities in the "heavy skill, light humanities" ideological trend, under the influence of British and American literature course face unprecedented challenges, the main problems of current is [1-4]: (1) the students are not interested in English and American literature course. Very important characteristic is the destruction of traditional cultural globalization lead to the marginalization of art and literature. Under the market economy system, the talent competition, students pay more attention to the employment practical courses, ignored the literature as the important role of humanities education key disciplines; (2) pay attention to the language ability, neglect the humanities. Under the guidance of this kind of wrong ideas, the teacher is usually carried out with the original word by word and sentence by sentence analysis, literature has a very high literary accomplishment, replaced by the analysis of sentence and discourse, and cannot guide students to appreciate the beauty of literature, the real hard to stimulate students' interest; (3) the importance of the course is not enough, reflected in the class less and reading environment, etc. Because the class time is too little, the teacher can't in the classroom teaching content, cannot interact with students, usually simply introduce literature genre, the major writers and works, and then let the students read the masterpiece of extracts, lead to the less active thinking, have no purpose to expand students' knowledge. Library is given priority to with examination classes, original English very few, some precious don't allow students to borrow the original works, the reading environment constrained; (4) the teaching material can't meet the needs of the course. Teaching material is the student to obtain the system knowledge, development the important tool of intelligence, improve the ideological and moral consciousness. Used by British and American literature teaching material chooses content, although all are English literature creation, but because of modern life far away from English countries, cannot meet the needs of the students understand the English national development. Some of the teaching material content can't adapt to the Chinese students' English practical needs. British and American literature course must reform the teaching content, changing the traditional teaching mode and evaluation system, in order to adapt to the development needs of the new situation, stimulate students interest in literature and learning enthusiasm, help students to learn creatively appreciation and understanding of literary works, expanding literary field of vision and improve the humanistic quality.

\section{Theoretical Basis of Constructivism}

Constructivism is a theory of knowledge and learning, which emphasizes the learner's initiative and think learning is the original knowledge of learners based on generating meaning and understanding of construction, and the process is often done in the social and cultural interaction. Of constructivism theory can also be simply interpreted as: knowledge is not obtained by teachers to teach, but learners in certain situations, the social and cultural background, with the help of others, using the necessary learning materials, and by means of meaning construction. As a result of learning is in a certain situation or social and cultural background, with the help of others through collaborative activities between people and realize the significance of the construction process, so the constructivism learning theory is that "situation", "collaboration", "session" and "meaning construction" is the four elements of learning environment. Constructivism theory has a profound ideological origin, different from the traditional learning theory and teaching thought, has the important guidance value for teaching. Based on the theory of constructivism teaching process is shown in Fig. 1.

View is as follows: the basis of constructivism theory of constructivism concept of knowledge, knowledge is only one explanation for the main body of the objective world, rather than the 
absolute truth, knowledge can't be in the form of entity exists outside the individual, different individuals were based on his experience to different construction of the same proposition, the student to the knowledge obtained only by actively constructing to complete; Constructivism learning theory, learning is a process of interaction with, is in a certain situation, the new knowledge and existing knowledge interaction of learners, the study is in certain situations, through construction actively, to obtain the significance of the construction process of the objective world; Constructivist view [5] of teachers, teachers are not transmit knowledge engineers, teachers' role is not to give students the truth, but rather on the significance of constructing student support, is a helper, guide students to construct knowledge with partners, teachers should according to the understanding of constructivism and the request to establish training goal; Constructivist view of students, learning is a process of constructing intrinsic mental representation, is an active process of construction, the learner is not passively absorb information, but actively construct information, on the one hand is the meaning of the construction on the new information, on the other hand also contains the transformation or restructuring of the original experience; Constructivism teaching view [6], teaching is not a one-way transfer knowledge to students by teachers can be completed, but acquired through the way of meaning construction, student-centered teaching process, emphasizes students' active exploration, active in knowledge discovery and the knowledge in the active construction of meaning.

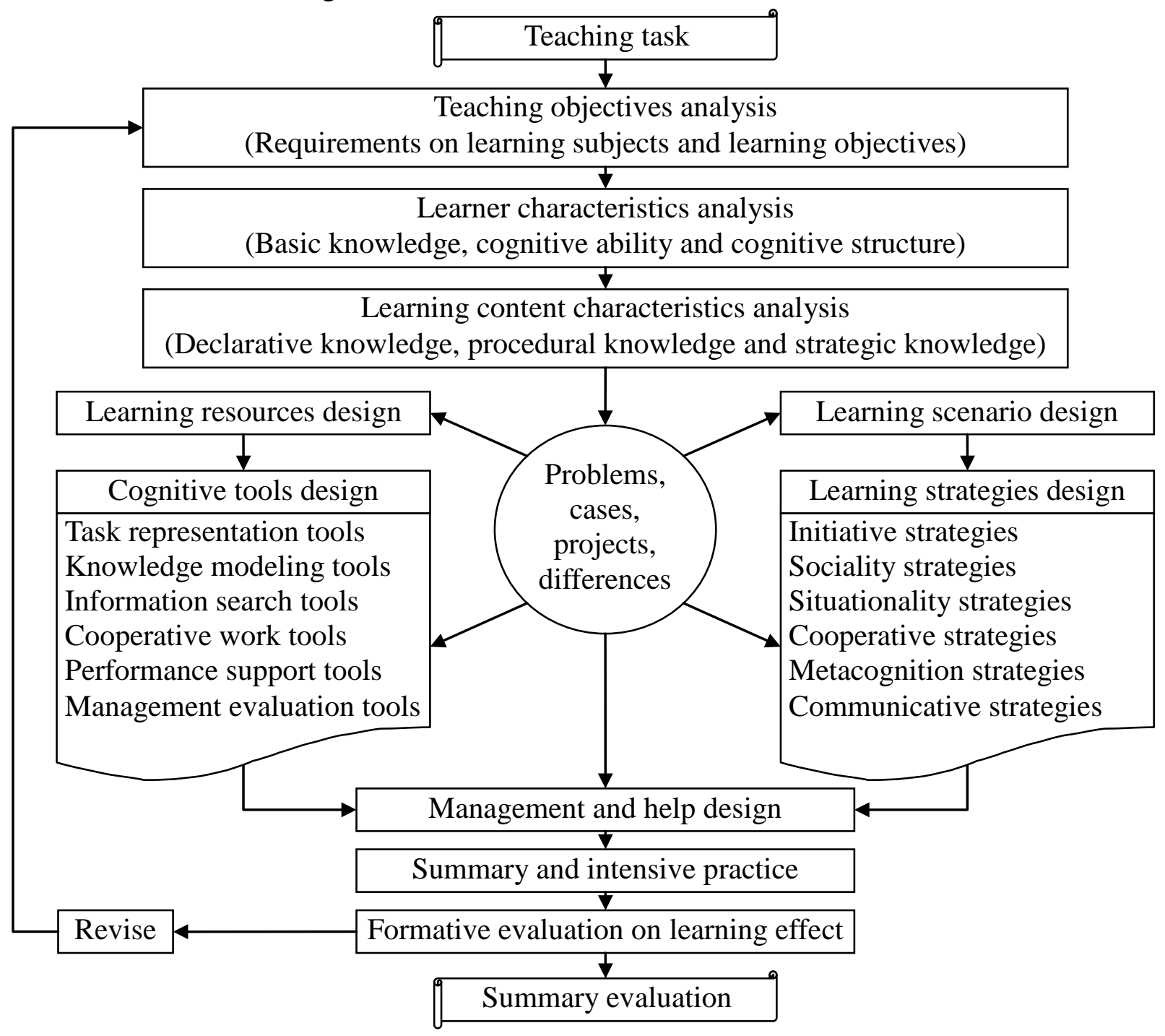

Fig. 1. Teaching process based on constructivism theory

Teaching mode is to point to in certain education ideology, teaching theory and learning theory under the guidance of, in the process of teaching activities in a certain environment, the stability of the structure. Constructivism theory advocates the teaching model is as follows (7-10] : anchored 
instruction model, with actual events or real problems for the "anchor", around the "anchor" to design the teaching activities, course material to allow students to carry out the inquiry activity, the teaching goal is to use the students master useful knowledge, promote the development of students ability to migrate, improve students' ability to analyze and solve problems, stimulate learning motivation; Scaffolding instruction model, teacher for students' learning structures, stents, the first to help learners to understand specific knowledge. With the aid of knowledge framework, learners to explore and solve problems independently and then gradually to skim bracket, make students explore independently, independent construction of meaning. , uncertainty about the nature of teaching process as a "clear teaching, the zone of proximal development structures, stents, the inquiry learning, diagnostic study effect, to withdraw support" and so on five links. Random access instruction model, learners can freely enter the same teaching content in different ways or different ways, for the same thing or the same question several aspects of understanding and the understanding. Basic teaching is "teaching content selection, teaching target analysis, presents the basic situation, randomized into the study, thinking development training, group cooperative learning, learning evaluation, the migration application". Cognitive apprenticeship teaching model, starting from the main problems in the reform of school education, the method of traditional apprenticeship in the core technology and it integrates new teaching pattern of school education. The model has the advantage of encouraging the real activities and evaluation, to arouse study motive, keep and migration, higher efficiency, effectively promote the development of learners' higher-order reasoning process.

\section{Teaching Strategies on English and American Literature}

Through in-depth analysis of constructivism theory, with reference to relevant literature of [11-14], combined with the authors' years of British and American literature teaching and research experience, put forward the teaching strategies are as follows:

(1) Multi-angle analysis of literary works. Constructivism thinks that in the process of learning, learners can form the angles of the concept of understanding, and in relation to the specific situation, forming background sexual experiences. This is used to guide teaching is helpful to learners in view of the specific situation construction scheme of problem solving. Effective penetration of modern literature, philosophy and psychology theory, improve the level of the student multiple perspectives analysis literature study British and American literature, to understand western culture. In British and American literature teaching practice, through specific text analysis, the modern western literary theory organically into them, let the students more in-depth understanding of the essence of the works and the message, and guide them to use. To deep understanding of British and American literature, it is necessary to understand some theories of western philosophy and psychology point of view, as Freud's psychoanalysis and consciousness stratification, Darwin's theory of evolution and existential Sutter. Readers can use such as structuralism, formalism and new historicism, feminism and the contemporary literary criticism methods, such as post-colonial interpretation work. Diversity of western culture and its genre embodies the western diverse ways of thinking and academic thought tradition, in spite of these schools have their unable to overcome the weakness, but can develop the thinking space, on the master of literature and teach more tension, at the same time, it broadens the horizons of students.

(2) Carrying out cultural teaching. Constructivism believes that learning is in a certain situation, the social and cultural background, with the help of others, namely through collaborative activities between people realize the significance of the construction process, "situation", "collaboration", "session" and "meaning construction" is the four elements of learning environment. Teachers should use various teaching materials and means to create cultural learning environment, stimulate students' learning motivation, to mobilize students' potential and imagination, to improve the students' interest in collaborative communication, so as to achieve the purpose of actively building cultural knowledge. Is culture teaching in English and American literature teaching, the national culture and tradition, social system and humanistic amorous feelings to understand and grasp, to get rich cultural knowledge, through the works of the author's thoughts and feelings, to influence 
learners; By culture teaching, cultural knowledge to a higher level of development, constantly expand the learners' cultural field of vision and thoughts, multinational culture awareness and language communication ability, cultivation mode of thinking and tolerance open emotional attitude, improve the overall quality; Through cultural integration, and improve the learners' thinking ability, through vivid and interesting literary works, to exert a subtle influence on the influence of the thought and life philosophy, to improve learners' comprehensive cultural quality.

(3) Make full use of multimedia assisted teaching. Constructivism learning theory emphasizes to create true "situation", the establishment situation as the necessary premise of "meaning construction". Multimedia technology is the most effective tool for creating real situation, can produce a realistic effect, as it were, stimulates the student to the main body status in construction and meaning. Multimedia to play a role in the teaching, must guide on the theory of constructivism thought, to give full play to the advantages of multimedia teaching, improve the quality of teaching, improve teaching effect. Therefore, the multimedia technology provides the thought under the guidance of constructivism teaching platform, is the material guarantee for the implementation of constructivism thought, and constructivism thought is the theoretical basis of the advantage of multimedia assisted instruction. British and American literature course determines the suitable for the characteristics of multimedia teaching. Based on computer multimedia teaching, with its advantages in the field of foreign language teaching with audio-visual and be able to use, change the teacher-centered, passive, one-way infusion of enclosed type teaching mode, to reduce the influence of teachers' personality characteristics of teaching activities. It presents the artistic expressiveness of teaching content and the strong appeal, easy to stimulate students' interest. It uses voice, text, images, animation, color, sound recording and music combination, enhancing the teaching of visual and vivid.

\section{Conclusion}

Constructivism is a revolution of contemporary education psychology, is replacing the traditional education in the field of dominant objectivism, become a basic concept in the field of education. Based on the theory of constructivism teaching, can optimize the students' cognitive structure, the original cause of the students' cognitive conflict, construct a new cognitive structure, consolidate the transfer and use the new cognitive structure. To construct to learners as the center, the new teaching process on the basis of the students' activities, make the teaching activities under the guidance of teachers, based on a real independent activities and explore, on the basis of formation is conducive to the healthy development of the students spirit and innovative ability loose teaching environment. Literature teaching of the humanities education for all-around development the important role in, British and American literature course is an important part of the humanities and culture education. Based on the constructivism theory, British and American literature course should adhere to the people-oriented teaching process and develop the students' innovation ability, thinking ability and independent appreciation ability, stimulating learning motivation and mobilize the enthusiasm, lets the student participate in the whole process of learning, research literature can let the students found that the relationship with the world, with the aid of literature's own rich connotation, to know and understand yourself, make a deep and thoughtful person.

\section{References}

[1] Y. Wang, "The present situation and countermeasures of the teaching of English and American literature," The Science Education Article Collects, vol. 7, no. 12, pp. 73-74, 2013.

[2] C. J. Liu, "Analysis of teaching situation and reform countermeasures of college English and American literature course," Journal of Nanchang College of Education, vol. 28, no. 10, pp. 145-145, 2013. 
[3] K. Kang, "Research on the present situation and countermeasures of English and American literature teaching," Journal of Changchun University of Science and Technology, vol. 7, no. 10, pp. 200-201, 2012.

[4] S. Zhou, "On the Current Situation of Teaching English and American Literature and Promotion Strategy," Journal of Hubei Correspondence University, vol. 28, no. 4, pp. 115-116, 2015.

[5] G. C. Zhang, "On the Constructivism Teacher thought," Education Science, vol. 22, no. 1, pp. 49-52, 2006.

[6] Human education network, "Teaching Ideas of Constructivism," http://www.pep.com.cn/xgjy/xlyj/xlshuku/xlsk1/etfz/201008/t20100827_814294.htm, 2016-9-25.

[7] K. K. He, "Constructivist learning theory and teaching model," http://www.ruiwen.com/news/95.htm, 2016-9-25.

[8] J. Liu, "Scaffolding teaching mode and classroom teaching," Journal of Guizhou Normal College, vol. 26, no. 3, pp. 66-70, 2010.

[9] T. Y. Cheng, "Review on the research of random access to teaching: review and prospect," Education Science Forum, vol. 30, no. 9, pp. 78-80, 2016.

[10] B. Li, Q. Zhang, "On the teaching mode of cognitive apprenticeship," Jiangxi Education Research, vol. 23, no. 12, pp. 16-19, 2006.

[11] L. Fan, "Research on the teaching of English and American Literature in Colleges and Universities under the output of culture," Chinese construction, vol. 61, no. 20, pp. 9-10, 2016.

[12] X. J. Li, "The Optimization of College English Culture Teaching in the Theory of Constructivism," Theory and Practice of Education, vol. 36, no. 6, pp. 57-58, 2016.

[13] Y. Han, "An analysis of multimedia English teaching based on constructivism," Science \& Technology Information, vol. 11, no. 27, pp. 187-187, 2014.

[14] F. L. Song, "The Mutimodality Teaching of English and American Literature Based on Revevance Theory," Journal of Xingyi Normal University for Nationalities, vol. 28, no. 4, pp. 67-69, 2014. 